\title{
Election preferences of the inhabitants of West Pomerania in local elections in the Third Republic of Poland
}

\begin{abstract}
Western Pomerania was said to be called as a stronghold of the left, for the Democratic Left Alliance both in the 1990s and at the beginning of the 21 st century achieved some of the best results in the country. Only after the parliamentary and presidential elections in 2005 and the local government elections in 2006, the electoral preferences changed towards the center of the political scene. The Civic Platform of the Republic of Poland turned out to be the change, Law and Justice to a lesser extent.

The article presents a political analysis of the voting preferences of the inhabitants of West Pomerania in the local government elections with regard to the three mentioned parties. The aim of the research was to analyze the direction in which the electorate goes. It was checked whether the SLD was permanently eliminated and how strong the dominance of the PO was. Furthermore it was examined whether PiS is a real threat to the PO RP and whether the SLD has a chance to regain its lost position.

It seems that regardless of the attempts made, the position of the SLD after the 2006 elections is stable and there are no indications that the Alliance could dominate the analyzed region again. However, in spite of the fact that since 2006 the PO enjoys high support, since 2014 PiS has been achieving better and better results, depriving the PO RP hegemon in its position in 2006-2014.
\end{abstract}

Key words: West Pomerania, local elections, electoral preferences, political party

\section{Prefactory Remarks}

F or a long time West Pomeranian was said to be a so-called stronghold of the left, as the SLD recorded one of the best election results in all kinds of elections in the scale of the country. This kind of opinion functioned both in the 1990s and at the beginning of the 21 st century. After the parliamentary and presidential elections in 2005 and self-government elections in 2006, it was possible to see a change in the voting preferences of the majority of residents participating towards the center of the political scene. The main beneficiary of this change turned out to be the Civic Platform of the Republic of Poland (PO RP), and the Law and Justice (PiS) to a lesser extent. (Chrobak, 2015, p. 259].

The article analyzes the electoral preferences of the inhabitants of West Pomerania during elections to organs of the local government ${ }^{1}$ in regard to the three groups mentioned above, which have enjoyed high support of voters both in the country and in the West Pomeranian region. The aim of the research was to analyze the direction in which the electorate goes. It was checked whether in Western Pomerania we can discuss of a permanent marginalization of SLD in the local government elections. In addition, it

${ }^{1}$ With the exception of elections to municipal councils, due to the slight amount of party committees and direct elections of city mayors, which will be devoted to a separate publication. 
was examined how strong the position of the PO is and if this party can be considered a hegemon in the scale of region. Then, it was analyzed whether PiS could seriously threaten the position of the PO RP and whether the SLD has a chance to regain its leader's position.

When analyzing electoral preferences during local government elections, no one must forget that local committees (Electoral Committees of Voters) established by non-party citizens play an important role in them. In addition, political groups that fear that the party's banner may have bad associations, often set up the KWW on the commune or poviat scale, the name of which does not refer to a given party in any way, despite the fact that its members are on the lists. Such actions obviously hinder the analysis of voting preferences. As the research focuses on the three mentioned parties and the aim is to analyze the scale of their support - committees established by non-parties citizens and also by other political parties under their own name or in a disguised name, were not taken into consideration.

The article adopts the typology of political parties after W.Sokół and M. Żmigrodzki (Sokół, Żmigrodzki, 2003, pp. 197-258). According to the ideological-programmatic criterion (depending on the period in which the analyzed groups operated), SLD and the Labour Union (UP) were defined as the left or the center-left. PO RP as center-right, center or center-left. PiS as center-right or the right. According to the criterion of the main ideological currents, SLD and UP were defined as social-democratic or social-liberal parties, PO RP as liberal or social-liberal, and PiS as Christian democracy. On the other hand, according to the criterion of the basic doctrinal stereotypes, the SLD and the UP were defined as social democratic groups, the PO RP as liberal, and PiS as conservative. In turn, according to the genetic-program criterion, SLD was defined as a post-communist party, UP as a Solidarity Left, and PO and PiS as post-Solidarity.

Bearing in mind the above, it should be remembered that the groups make it difficult to classify them by, e.g.: having a left economic program and expressing right-wing ideological issues etc., and by frequent changes to the program in order to better meet the expectations of voters in order to win their votes. (Sielski, 2008, pp. 17-27; Godlewski, 2008, pp. 15-19).

\section{Election preferences to the Regional Council of the West Pomeranian Voivodeship}

When analyzing the results of the elections to the Regional Council of the West Pomeranian Voivodeship (SWZ), it is easiest to show what electoral preferences the inhabitants of Western Pomerania had, due to the least number of committees established by entities other than political parties. However, due to the fact that the three analyzed groups (SLD, PO RP and PiS), creating election committees in 1998-2018, often formed coalitions with various parties - let's remind that in 1998 the PO and PiS did not exist yet - it makes it difficult to analyze voting preferences.

When examining the composition of the election committees in which SLD participated in 1998-2018, it should be noted that in 1998 the Alliance went on its own to the elections in the "SLD" committee, winning 22 seats (then the SWZ had 45 councilors and since 2002 it has had 30 councilors (Czerwiński, 2003, pp. 139-141; Ptak, 2010, 
pp. 148-149)). However, it was not yet a political party, but a broad coalition of number of left-wing political formations (created in 1991), the strongest of which was the Social Democracy of the Republic of Poland (SdRP), founded in 1990 after the self-dissolution of the PZPR (some activists at the same time created The Social Democratic Union of the Republic of Poland, which in April changed its name to the Polish Social Democratic Union, in 1991 was dissolved (Jabłonowski, Janowski, Sołtysiak, 2015, pp. 6-33; Dudek, 1997, pp. 85-89)). It was only in 1999 that the aforementioned coalition transformed into a political party known as SLD (Tomczak, 2004, pp. 55-56; Buhler, 1999, pp. 700-703).

In the following elections in 2002, SLD joined the coalition with the UP in the KKW Democratic Left Alliance - the Labour Union (KKW SLD-UP), in which a year earlier, that is in 2001, he ran in the parliamentary elections. As is known, these were two leftwing groups, with the difference that one came from the former PZPR, while the other from the left wing of Solidarity (Sieklucki, 2006, pp. 23-24; Tomczak, 2008b, pp. 8-9). At that time, 13 councilors (PKW) were introduced.

However, during the elections in 2006, the Alliance participated in a broad center-left coalition together with three other groups known as KKW SLD+SDPL+PD+UP - Left and Democrats (LiD), winning 5 seats. In this configuration, we dealt with three leftwing or center-left groups (social-democratic or social-liberal) and one centrist (liberal or social-liberal) depending on the period. Social Democracy of Poland (SDPL) was established in 2004 as a result of a split in the SLD, while the Democratic Party (PD) was established in 2005 from the transformation of the Labour Union (UW) (Peszyński, 2008, pp. 81-84; Danel, 2008, p. 72; Paradowska, 2006). In this situation, voters with preferences not only left-wing or center-left, but also centrist (i.e. social-democratic, social-liberal or liberal) could vote for the LiD (Tomczak, 2007, pp. 83-87; Drzonek, 2006, pp. 159-162).

In 2010, the LiD coalition no longer existed (it broke up in 2008) and the Alliance went to the elections under its own name, KW Democratic Left Alliance (KW SLD), but its lists also included politicians, e.g. from UP, Women's Party and Zieloni 2004 (Piasecki, 2012, p. 307), that is left-wing and center-left (social democratic and social-liberal) groups. A committee constructed in this way could vote not only for people with left-wing or center-left (social-democratic and social-liberal) preferences, but - as the founders of the committee certainly hoped for - also those with feminist and ecological views. At that time, 6 seats (PKW) were obtained.

In 2014, the Alliance created the KKW Democratic Left Alliance - the Left Together (KKW SLD-LR), which won 4 seats. The committee was also made up of the UP and the National Party of Pensioners and Retirees (KPEiR). In addition, the election lists to the SWZ also included politicians from the Democratic Party and smaller left-wing or center-left formations (Kowalczyk, 2015, pp. 62-63). In turn, in 2018, the Alliance re-established KKW SLD-LR, which was co-created by the aforementioned UP and SDPL. Moreover, the committee included smaller left-wing and center-left formations. On the other hand, in 2018 KPEiR finally joined the Civic Coalition (SLD; Coalition). Only 1 seat (PKW) was won at that time.

Analyzing with which groupings SLD formed the election committees ran from the aforementioned lists, it cannot be unequivocally said that voters who voted for the 
above-mentioned committees co-created by the Alliance showed only left-wing (social democratic) electoral preferences. In this situation, it seems that the above-mentioned committees also attracted - though probably in smaller parts - voters with center-left and center preferences (social liberal and liberal).

When examining the composition of the election committees for the SWZ which was created or co-created by the PO RP in 2002-2018, in 2002, as part of the nationwide agreement of the leaders of both parties, the PO created a joint committee with PiS: KKW Civic Platform - Law and Justice (Piasecki, 2012, p. 168), who introduced 3 councilors (PKW). In this situation, the committee could receive votes cast by voters characterized by both center and center-right preferences (liberal and conservative). However, the cooperation between the two parties ended after the parliamentary elections and the presidential elections in 2005, when the so-called POPiS was not created in the Sejm Coalition (Roszkowski, 2007, pp. 307-310; Sielski, 2006, pp. 125-126; Górka, 2017, pp. 190-204). Since then, both parties have become the greatest rivals, and judging by the temperature of the dispute over the past few years, it can be said that they are downright hostile to each other.

In 2006, the Civic Platform went to the elections on its own, creating the KW Civic Platform RP (KW PO RP), which won 12 seats. From this election, one can see the beginnings of cooperation with the Polish People's Party (PSL), as the PO RP grouped its election lists with the People's (Marszałek-Kawa, 2007, pp. 199-215; Tomczak, 2008a, pp. 35-39; Drzonek, 2007, pp. 20-25; Ustawa). In turn, after the elections, both parties formed a number of coalitions in the regional assemblies. Also in the next two elections in 2010 and 2014, the Platform independently created unchanged committees, (Piasecki, 2012, p. 304; Krzeszewska, 2016, pp. 73-78), winning 16 and 12 seats in order (PKW).

However in 2018 the party in question was part of a wider coalition of the KKW Platform. Modern Civic Coalition (KKW PN KO), which won 13 seats (PKW). The joint committee of Platforma and Nowoczesna was established in 2018. In turn, Nowoczesna itself was established in 2015 (initially as an association) before the parliamentary elections. The Civic Platform probably hoped that by joining forces with Nowoczesna it would avoid a possible blurring of votes, as both parties sought a similar electorate located in the center or in the center-left part of the political scene. In the case of the committees created or co-created by the PO, it can be seen that initially creating a coalition with PiS, not only the centrist electorate, but also the center-right (liberal and conservative) electorate was soughting. Subsequently, the party remained in the broad center of the political scene, and then turned to the left, fighting for the electorate not only from the centrist, but also from the center-left (liberal and social liberal).

When analyzing the composition of the election committees to the SWZ formed by PiS in 2002-2018, as already mentioned, PiS in 2002 co-created a committee with the PO. However, already in 2006, the party went to the elections on its own, creating the KW Law and Justice party (KW PiS), which introduced 7 councilors. At the same time, lists with Self-Defence RP and the League of Polish Families (LPR) were blocked, which was, i.e. the result of the cooperation of these groups in the Sejm (Kowalczyk, Tomczak, 2008, pp. 54-55). Also in 2010, PiS created a committee of the same name on its own, gaining 5 seats (Piasecki, 2012, p. 305; Państwowa Komisja Wyborcza). 
In turn, despite the fact that in 2014 PiS created a committee under the unchanged name, the lists also included representatives of Zbigniew Ziobro's Solidarity Poland (in 2018 the name was changed to Solidarna Polska) and Jarosław Gowin's Polish Together (PRJG). Six seats were won then. "Solidarna Polska" was established in 2012 as a result of Z. Ziobro and his supporters left PiS a year earlier. On the other hand, PRJG (in 2015 it changed its name to Polish Together - United Right) was established in 2014 as a result of the departure of J. Gowin from the PO RP and his supporters. In 2017, as a result of expanding its composition with new political formations, it transformed into an Agreement headed by J. Gowin (Kowalczyk, 2015, p. 62). Also in 2018, PiS for the fourth time created a committee under the unchanged name, from which the candidates from Solidarna Polska and the Agreement ran. At that time, 11 councilors (Państwowa Komisja Wyborcza) were introduced.

Referring to the committees created by SLD and PO RP, it can be seen that PiS has remained the most consistent when it comes to keeping the same name. Moreover, it formed a committee whose name, regardless of whether the party went independently or accepted candidates from other parties, was always unequivocally associated with the name of the party. Besides short cooperation with the PO, the committee formed by PiS looked for voters characterized by center-right and right-wing (conservative) views.

Analyzing the results of the elections to the SWZ, it can be seen that during the elections in 1998 and 2002, left-wing preferences prevailed, as evidenced by the victory of the SLD and SLD-UP committees. In the next two elections, the LiD and SLD committees were ranked third and second, and in 2014 and 2018 the SLD-LR committee was outside the top three committees. The change in the voting preferences of the majority of voting residents of the region has been visible since the 2006 election, which will be consistently won in each subsequent election by the Platform (jointly with Nowoczesna in the last one), which was then at the center of the political scene. Natomiast PiS coraz bardziej umacnia się na pozycji drugiej siły politycznej. On the other hand, PiS is increasingly strengthening its position as the second political force. In 2002, in the joint committee with the Platform, they were not in the top three, while in 2006 he took second place, in two consecutive elections he was placed third, only to return to second place (Państwowa Komisja Wyborcza) in the last elections. See tables 1 and 2 .

Results of elections of selected committees to the SWZ in 1998-2018

Table 1

\begin{tabular}{|c|c|c|c|c|c|c|c|c|c|c|c|c|c|c|c|c|c|c|c|c|c|c|c|c|}
\hline \multirow{3}{*}{$\begin{array}{c}\text { Party's } \\
\text { name }\end{array}$} & \multicolumn{24}{|c|}{ Victories in presidential counties and cities } \\
\hline & \multicolumn{4}{|c|}{1998} & \multicolumn{4}{|c|}{2002} & \multicolumn{4}{|c|}{2006} & \multicolumn{4}{|c|}{2010} & \multicolumn{4}{|c|}{2014} & \multicolumn{4}{|c|}{2018} \\
\hline & $\mathbf{I}^{1}$ & $\mathbf{I I}^{2}$ & IIII $^{3}$ & $i^{4}$ & I & II & III & i & I & II & III & i & I & II & III & i & I & II & III & i & I & II & III & i \\
\hline PO RP & \multirow{2}{*}{\multicolumn{4}{|c|}{-}} & - & - & - & $\mathrm{X}^{\mathrm{a}}$ & $\mathrm{X}$ & - & - & - & $X$ & - & - & - & $\mathrm{X}$ & - & - & - & $X$ & - & - & - \\
\hline PiS & & & & & - & - & - & & - & $\mathrm{X}$ & - & - & - & - & $\mathrm{X}$ & - & - & - & $\mathrm{X}$ & - & - & $\mathrm{X}$ & - & - \\
\hline SLD & $X$ & - & - & - & $X$ & - & - & - & - & - & $X$ & - & - & $X$ & - & - & - & - & - & $X$ & - & - & - & $X$ \\
\hline others & - & $\mathrm{X}$ & $\mathrm{X}$ & - & - & $\mathrm{X}$ & $\mathrm{X}$ & - & - & - & - & - & - & - & - & - & - & $\mathrm{X}$ & - & - & - & - & $\mathrm{X}$ & - \\
\hline
\end{tabular}

${ }^{1}$ First place; ${ }^{2}$ Second place; ${ }^{3}$ Third place; ${ }^{4}$ Place out of the top three; ${ }^{a}$ KWW PO-PiS.

Source: Own study based on PKW data. 
Results of the elections (the first three committees) to the SWZ in 1998-2018

\begin{tabular}{|c|c|c|c|c|c|c|}
\hline & \multicolumn{6}{|c|}{ The names of the first three committees } \\
\hline & 1998 & 2002 & 2006 & 2010 & 2014 & 2018 \\
\hline \multirow{3}{*}{ SWZ } & SLD & KKW SLD-UP & KW PO RP & KW PO RP & KW PO RP & KKW PNKO \\
\hline & AWS & KW Samoobrona RP & KW PiS & KW SLD & KW PSL & KW PiS \\
\hline & UW & KW LPR & KKW LiD & KW PiS & KW PiS & KWW BS ${ }^{a}$ \\
\hline
\end{tabular}

${ }^{a}$ KWW Independent local government official.

Source: Own study based on PKW data.

The level of support is better seen when you take into account the number of seats won and the percentage of votes won. After the domination of the Alliance in 1998 and 2002 (together with the UP), when 22 and 13 councilors were introduced, the next elections brought worse and worse results. The number of seats won from four consecutive elections, starting from 2006, amounted to: 5, 6, 4 and 1. It can be seen that the SLD (regardless of whether it was in the LiD coalition, alone or in the Left Together coalition) was getting less and less support from the elections to the elections, in relation to the previous elections. In 2002, its support was $2.16 \%$ lower than in 1998, in 2006 it was $14.72 \%$ lower than in 2002, in 2010 it was only $0.07 \%$ higher than in 2006, in 2014 in 2018 lower by $6.70 \%$ than in 2010 , and in 2018 lower by $2.74 \%$ than in 2014 . Also in regard to the PO RP and PiS, the Alliance recorded only losses since 2006. Beginning from the aforementioned 2006, in relation to the Polish OP, the result was worse in each subsequent election by $14.91 \%, 22.28 \%, 20.12 \%$ and $22.96 \%$. However, in relation to PiS, the result was weaker by $2.37 \%, 0.15 \%, 7.47 \%$ and by $17.72 \%$ (Państwowa Komisja Wyborcza). The above results show a downward trend, and thus do not indicate that the SLD - so far - could threaten the position of both the PO RP and PiS in Western Pomerania. See table 3.

Since 2006, the platform has won 12,16,12 and 13 seats in the SWZ (in the last elections together with Nowoczesna). In addition, it won the elections each time and was the main party in the coalition in power in the Seymik, always having its marshal. Looking at the number of seats won, you can see a certain stabilization and a period in which the party was a hegemon, independently having a majority in the Sejmik in 2010. In 2006, the support of the Platform was higher by $22.16 \%$ than in 2002, in 2010 by $7.44 \%$ higher than in 2006, in 2014 by $8.86 \%$ lower than in 2010 and in $20180.10 \%$ higher than in 2014. Jak widać wyniki wyborów z lat 2014 i 2018 były nieco słabsze niż z lat 2006 i 2010.As one can see, the results of the elections in 2014 and 2018 were slightly weaker than in 2006 and 2010. In turn, referring to the results of PiS and SLD, the Platform, from 2006, had better results in relation to PiS by $12.54 \%, 22.13 \%$, $12.65 \%$ and $5.24 \%$. It can be seen that only in the last elections PiS has significantly shortened the distance. However, with regard to SLD, also counting from 2006, the Platform had better results by $14.91 \%, 22.28 \%, 20.12 \%$ and by $22.96 \%$ (Państwowa Komisja Wyborcza). See table 3.

Observing the results of PiS, it can be noticed that this party is slowly strengthening in the region, and after the last elections in 2018, it has consolidated its position as the second political force in the Sejmik. As of 2006, PiS won the following number of seats: 7, 5, 6 
and 11. In 2006, PiS had 9.62\% more support than in 2002, in 2010 it was $2.15 \%$ lower than in 2006, in 2014 higher by $0.62 \%$ than in 2010, and in 2018 higher by $7.51 \%$ than in 2014. In turn, in relation to SLD, counting from 2006, PiS had better results by $2.37 \%$, $0.15 \%, 7.47 \%$ and $17.72 \%$. However, compared to the Platform, PiS had results weaker by $12.54 \%, 22.13 \%, 12.65 \%$ and by $5.24 \%$ (PKW). In this situation, it can be seen that the SLD is not able to threaten PiS's second position in the Sejmik. However, despite the fact that $\mathrm{PiS}$ in the recent elections has clearly shortened the distance to the PO, it seems that the position of the PO RP in the SWZ as a leader remains unchallenged. See table 3.

Table 3

The number of seats, the percentage of votes and the increase or decrease in votes in the elections to the SWZ in 1998-2018

\begin{tabular}{|c|c|c|c|c|c|c|c|c|c|c|c|c|c|c|c|c|c|}
\hline \multirow{2}{*}{$\mathbf{K}^{\mathrm{a}}$} & \multicolumn{2}{|c|}{1998} & \multicolumn{3}{|c|}{2002} & \multicolumn{3}{|c|}{2006} & \multicolumn{3}{|c|}{2010} & \multicolumn{3}{|c|}{2014} & \multicolumn{3}{|c|}{2018} \\
\hline & $\mathbf{M}^{\mathbf{b}}$ & $\% g^{\prime}$ & M & $\%$ gl & $\mathbf{P} / \mathbf{S}^{\mathbf{d}}$ & $\mathbf{M}$ & $\%$ gl & $\mathbf{P} / \mathbf{S}$ & M & $\%$ gl & $\mathbf{P} / \mathrm{S}$ & M & $\%$ gl & $\mathbf{P} / \mathrm{S}$ & M & $\%$ gl & $\mathbf{P} / \mathbf{S}$ \\
\hline SLD & 22 & 35.33 & 13 & .17 & \begin{tabular}{|l|}
-2.16 \\
\end{tabular} & 5 & 18.45 & -14.72 & 6 & 18.52 & +0.07 & 4 & 11.82 & -6.70 & 1 & 9.08 & -2.74 \\
\hline $\mathrm{PO}$ & & & & & & 12 & 33.36 & +22.16 & 16 & 40.80 & +7.44 & 12 & 31.94 & \begin{tabular}{|l|}
-8.86 \\
\end{tabular} & 13 & 32.04 & +0.10 \\
\hline PiS & & & 3 & & & 7 & 20.82 & +9.62 & 5 & 18.67 & -2.15 & 6 & 19.29 & +0.62 & 11 & 26.80 & +7.51 \\
\hline Others & 23 & 48.93 & 14 & 37.92 & - & 6 & 17.07 & - & 3 & 12.96 & - & 8 & 30.44 & - & 5 & 23.38 & - \\
\hline
\end{tabular}

${ }^{\mathrm{a}}$ The name of the committee; ${ }^{\mathrm{b}}$ Number of seats; ${ }^{\mathrm{c}} \%$ votes; ${ }^{\mathrm{d}}$ Increase or decrease in votes in $\%$.

Source: Own study based on PKW data.

\section{Elections to poviat councils in the West Pomeranian Voivodeship}

In 1998 - as already mentioned - both the PO and PiS did not exist yet. In turn, the SLD in the elections to poviat councils in the West Pomeranian region registered election committees under its own name in all 17 poviats (let us remind you that in 1998 the Łobeski poviat did not exist yet). However, depending on the poviat, there were three different names for the Alliance committee: "National Electoral Committee of the Democratic Left Alliance" (KrKW SLD), "List of the Democratic Left Alliance"” (Lista SLD) or "SLD" (Chrobak, 2014, pp. 177-181).

During the elections in 2002, the Alliance, together with the UP, registered committees in all 18 poviats, with the same name as for the SWZ, ie KKW SLD-UP. In 2006, the Alliance co-founded the LiD committee, with the same name as for the SWZ. However, the committees have been registered only in 10 poviats (Białogard, Choszczno, Drawsko, Goleniów, Kołobrzeg, Koszalin, Pyrzyce, Sławno, Stargard and Wałcz), while in the remaining 8 (Gryfice, Gryfino, Kamień, Łobez, Myślibórz, Police, Szczecinek and Świdwin), SLD members, if they applied for seats, were from the lists of committees whose names did not suggest a specific party affiliation, and thus it was impossible to know whether they were committees with a left-wing, center-left or other (Państwowa Komisja Wyborcza) program.

After the aforementioned break-up of the LiD coalition, in the 2010 elections to poviat councils, the Alliance formed committees under the same name as for the SWZ, ie KW SLD. He registered his lists in 13 poviats (Białogard, Drawsko, Goleniów, Gryfice, Gryfino, Kołobrzeg, Koszalin, Myślibórz, Police, Pyrzyce, Sławno, Stargard oraz Szczecinek), 
and in the 5 others (Choszczno, Kamień, Łobez, Świdwin and Wałcz) alliance candidates, if they took part in the elections, had to run from the lists of other committees, the names of which did not indicate a specific party affiliation. The exception was the Choszczno poviat, in which the KWW Social Agreement and the Left of the Choszczno Poviat was registered, which obtained 4 seats (Państwowa Komisja Wyborcza). Its name suggested that the list includes, among others, candidates with left-wing or center-left views.

However, already in 2014 the Alliance in individual poviats - similarly to the SWZ - created committees under the new name KKW SLD-LR. He registered his lists in 12 poviats (Białogard, Choszczno, Drawsko, Goleniów, Gryfino, Kołobrzeg, Myślibórz, Police, Pyrzyce, Sławno, Stargard and Szczecinek), while in the remaining 6 (Gryfice, Kamień, Koszalin, Łobez, Świdwin and Wałcz) if candidates applied for seats of the Alliance, it was from the lists of other committees (Państwowa Komisja Wyborcza).

In 2018, SLD - the same as to the SWZ - again created committees in individual poviats with the unchanged name of KKW SLD-LR. It registered its lists in 11 poviats (Białogard, Choszczno, Drawsko, Goleniów, Gryficki, Gryfiński, Kołobrzeg, Myślibórz, Police, Pyrzyce, Szczecinek), and in the remaining 7 (Kamien, Koszalin, Łobez, Sławno, Stargard, Świdwin and Wałcz) if they applied for a seat in the Seymik, alliance's contenders also came from the lists of other committees. The exception was the Stargard poviat, in which KWW Left-Wing Electoral Agreement - Our Stargard was registered, which received one mandate (PKW). Its name suggested that there were left-wing or center-left candidates on the list.

Analyzing the composition of the election committees to the councils of land poviats created by the PO RP in 2002-2018, it can be seen that in 2002 the party established a committee under its own name, the Civic Platform Committee of the Republic of Poland, which registered lists only in 2 poviats (Police and Pyrzyce). In 15 poviats (Białogard, Choszczno, Drawsko, Goleniów, Gryfice, Gryfino, Kamień, Kołobrzeg, Koszalin, Łobez, Myślibórz, Sławno, Stargard, Świdwin and Wałcz), Platform members, if they applied for seats, were from the lists of other committees whose names did not indicate any specific party affiliation. On the other hand, in the Szczecin poviat, a joint committee of the PO RP and PiS was registered: KWW POPiS Szczecinek, which did not obtain any mandate (Państwowa Komisja Wyborcza).

In 2006, the Platform independently created a committee under the name of the SWZ: KW PO RP, which registered lists in 15 poviats (Białogard, Choszczno, Goleniów, Gryfice, Kamień, Kołobrzeg, Koszalin, Myślibórz, Police, Pyrzyce, Sławno, Stargard, Szczecinek, Świdwin and Wałcz). In turn, in 3 poviats (Drawsko, Gryfino and Łobez), the PO candidates ran from the lists of other committees. In 2010, the PO RP re-established a committee named as SWZ, which registered lists in 17 poviats, with the exception of the Lobeski poviat. Also in 2014, the Platform for the third time created the Committee KW PO RP, i.e. as for the SWZ, which registered lists in 15 poviats (Białogard, Choszczno, Goleniów, Gryfice, Gryfino, Kamień, Kołobrzeg, Koszalin, Myślibórz, Police, Pyrzyce, Sławno, Stargard, Szczecinek and Wałcz). On the other hand, in 3 poviats (Drawsko, Łobez and Świdwin), the applicants of the PO RP, if they started, were from the lists of other committees (Państwowa Komisja Wyborcza).

In turn, in 2018, the Platform together with Nowoczesna created KKW PN-KO, which registered lists in 15 poviats (Białogard, Choszczno, Goleniów, Gryfice, Gryfino, 
Kamień, Kołobrzeg, Koszalin, Myślibórz, Police, Pyrzyce, Sławno), Stargard, Szczecinek and Wałcz). In turn, in 3 poviats (Drawsko, Łobez and Świdwin), the members of the Platform, if they applied for seats, were on the lists of other committees (Państwowa Komisja Wyborcza).

Examining the election committees to councils of land poviats formed by PiS in 2002-2018, it draws attention to the fact that in 2002 PiS did not register a committee under its own name in any poviat, but as already mentioned, only in the poviat of Szczecin it created a joint committee together with the Platform. In this situation, any PiS candidates had to run from the lists of other committees. In turn, during the elections in 2006-2014, PiS - as for the SWZ - registered committees under its own name KW PiS in 17 poviats, each time excluding the Łobeski poviat. It was not until the 2018 elections that it created committees in all 18 poviats, under the unchanged name. As it is easy to notice, PiS, as in the elections to the Seymik, was the only grouping which was registering committees under its own name, regardless of whether it went alone or with candidates from other parties on its lists. Moreover, it should be emphasized that since 2006 PiS, unlike other parties, has registered committees in practically all poviats of the voivodship (Państwowa Komisja Wyborcza).

Analyzing the election results, it can be seen that no other party won such a huge support as the SLD and SLD-UP committees in 1998 and 2002 gained. In the 1998 election, the Alliance registered lists in all poviats, of which it took first place in 14 and second in three. In 2002, the SLD-UP committee also registered lists in all poviats, achieving an equally good result. He won the best result in 13 poviats, in 4 poviats the second place and in 1 poviat won the 3rd place. However, in each subsequent election, support for the committees co-created by the SLD systematically decreased. In 2006, the LiD coalition registered lists in 10 poviats, of which only in 1 was ranked first, while in 3 it was ranked second and third, and in the next 3 it was placed outside the top three. A similar situation took place in 2010, with the difference that SLD registered committees in 13 poviats. Again, only in 1 it gained victorious, in 3 won second and third, and the remaining 6 achieved a result beyond the top three. The situation was even worse in 2014, when the SLD-LR coalition registered committees in 12 poviats. It was the first time that in none was victorious, only in 1 came second, in 3 thirds, and the remaining 8 scored beyond the top three.On the other hand, it was the weakest in 2018, when the SLD-LR coalition registered committees in 11 poviats. In none of them won the first or even the second place, in 2 only the third position, and in the remaining 9 it was achieved beyond the top three (Państwowa Komisja Wyborcza). The results of the elections of committees co-created or created by the Alliance to individual poviat councils, show that the position of SLD in Western Pomerania has clearly and permanently weakened since 2006. See tables 4 and 5 .

Examining the results of the Platform, it can be noticed that in spite of the fact that it has obtained the greatest number of victories in individual poviat councils since 2006, it has never even come close to the results of SLD and SLD-UP in 1998 and 2002, when the left wing enjoyed the greatest support among voters. However, this does not change the fact that since the 2006 election there has been a change in the voting preferences of the majority of voters in individual poviats. In 2002, the PO RP independently registered only 2 committees, one of which was placed third, and the other was outside the top three. The situation has definitely changed since the aforementioned 2006. Then the Platform 
registered 15 committees, 7 of which obtained the best result, 3 took second place, 2 won the third position, and 3 were outside the top three. The best result was achieved by the PO RP in 2010. It registered a total of 17 committees, of which 11 were placed first, 4 in second, one in third, and outside the top three. In 2014, the Platform registered committees in 15 poviats. Despite achieving the best result compared to other parties, this party noted less support than in the previous elections. The best result was obtained in 4 poviats, in 7 they came second, in 3rd position - third, and in 1 besides the first three. On the other hand, the combined forces of the Platform and Nowoczesna in 2018 slightly improved the situation. A total of 15 committees were registered, 6 of which won first place, 4 were second, 2 were third, and 3 were outside the top three (Państwowa Komisja Wyborcza). See tables 4 and 5.

Analyzing the results of PiS, it can be noticed that although this party had registered the most election committees in individual poviats since 2006, during the elections in 2002-2010 it was second not only to the PO, but also to the SLD. Only in 2014, with a minimal lead, it took second place, and in 2018 it clearly strengthened its position, leaving the committees co-created by SLD-LR far behind. In 2002, PiS did not register any committee on its own. On the other hand, in the next three elections, it formed committees in 17 poviats each time. In 2006, PiS committees did not win in any of the poviats, in 1 they took second place, in 6 - third, and in 10 they were beyond the top three. In 2010, PiS achieved the weakest result, as it did not take first or second place in any of the poviats, in 4 it was placed third, and in the remaining 13, it was not in the top three. There was a slight improvement in 2014, when no victories were again achieved, while in 2 poviats they came second, in 4 th place third, and in 11 outside the top three. The aforementioned clear improvement took place during the 2018 election, during which PiS registered committees in all poviats. For the first time there were victories in 3 poviats, in 6 poviats they were second, in 8 third, and in 1 apart from the first top three (Państwowa Komisja Wyborcza).The above results show that until 2018 on the scale of land poviats, PiS had to fight for the second position with committees co-created by the SLD. Only the last election showed that the left/center-left is no longer a threat and PiS may try to compete with the PO. See tables 4 and 5.

Examining the support enjoyed by the committees created or co-created by the SLD, the Civic Platform and the PiS in individual poviat councils, it should be emphasized that committees established by non-partisan groups of citizens or parties, but with names that prevented their identifications. See tables 4 and 5.

Table 4

Results of the elections of selected parties in the elections to councils of land poviats in Western Pomerania in 1998-2018

\begin{tabular}{|c|c|c|c|c|c|c|c|c|c|c|c|c|c|c|c|c|c|c|c|c|c|c|c|c|}
\hline \multirow{3}{*}{$\begin{array}{l}\text { Name } \\
\text { of the } \\
\text { party }\end{array}$} & \multicolumn{24}{|c|}{ Victories in poviats } \\
\hline & \multicolumn{4}{|c|}{1998} & \multicolumn{4}{|c|}{2002} & \multicolumn{4}{|c|}{2006} & \multicolumn{4}{|c|}{2010} & \multicolumn{4}{|c|}{2014} & \multicolumn{4}{|c|}{2018} \\
\hline & $I^{1}$ & $\mathrm{II}^{2}$ & $\mathrm{III}^{3}$ & $\mathbf{i}^{4}$ & I & II & III & $\mathbf{i}$ & I & II & III & $\mathbf{i}$ & I & II & III & i & I & II & III & i & I & II & III & i \\
\hline PO RP & \multirow{2}{*}{\multicolumn{4}{|c|}{ - }} & 0 & 0 & 1 & 1 & 7 & 3 & 2 & 3 & 11 & 4 & 1 & 1 & 4 & 7 & 3 & 1 & 6 & 4 & 2 & 3 \\
\hline PiS & & & & & 0 & 0 & 0 & 0 & 0 & 1 & 6 & 10 & 0 & 0 & 4 & 13 & 0 & 2 & 4 & 11 & 3 & 6 & 8 & 1 \\
\hline SLD & 14 & 3 & 0 & 0 & 13 & 4 & 1 & 0 & 1 & 3 & 3 & 3 & 1 & 3 & 3 & 6 & 0 & 1 & 3 & 8 & 0 & 0 & 2 & 9 \\
\hline Others & 3 & 14 & \begin{tabular}{|l|}
17 \\
\end{tabular} & - & 5 & 14 & 16 & - & 10 & 11 & 7 & - & 6 & 11 & $\mid 10$ & - & 14 & 8 & 8 & - & 9 & 8 & 6 & - \\
\hline
\end{tabular}

${ }^{1}$ First place; ${ }^{2}$ Second place; ${ }^{3}$ Third place; ${ }^{4}$ Place out of the top three.

Source: Own study based on PKW data. 
Results of the elections (the first three committees) to councils of land poviats in Western Pomerania in 1998-2018

\begin{tabular}{|c|c|c|c|c|c|c|}
\hline \multirow[t]{2}{*}{ Poviat } & \multicolumn{6}{|c|}{ The names of the first three committees } \\
\hline & 1998 & 2002 & 2006 & 2010 & 2014 & 2018 \\
\hline 1 & 2 & 3 & 4 & 5 & 6 & 7 \\
\hline \multicolumn{7}{|c|}{ The counties included in the constituency No. 41 in the elections to the Sejm of the Republic of Poland } \\
\hline \multirow[t]{3}{*}{ Goleniów } & SLD & KWW SLD-UP & KW PO RP & KW PO RP & KW PSL & KKW PNKO \\
\hline & $\mathrm{KW}$ „IS”bw & KWW WiR ${ }^{f}$ & KW PSL & KW PSL & KW PO RP & KW PSL \\
\hline & $\mathrm{PS}^{\mathrm{bx}}$ & KW PSL & KKW LiD & KW SLD & KKW SLD LR & KW PiS \\
\hline \multirow[t]{3}{*}{ Gryfice } & SLD & KWW SKWR ${ }^{\mathbf{a}}$ & KWW IR ${ }^{u}$ & KW PSIR ${ }^{\text {ah }}$ & KW PO RP & KKW PNKO \\
\hline & $\mathrm{MdM}^{\text {by }}$ & KWW SLD-UP & KW PO RP & KW PO RP & KW PSIR ${ }^{\text {ah }}$ & KW PiS \\
\hline & AWS & KW SRP ${ }^{\mathrm{ck}}$ & KWW UDP ${ }^{v}$ & KWW ZG ${ }^{a i}$ & KW PSL & KW PSIR ${ }^{\text {ah }}$ \\
\hline \multirow[t]{3}{*}{ Gryfino } & Lista SLD & KWW SLD-UP & KWW IS & KWW IS ${ }^{g}$ & KWW IS & KWW IS \\
\hline & AWS & KWW IS & KWW BBSw & KWW BBS" & KW PSL & KKW PNKO \\
\hline & $\mathrm{PS}^{\mathrm{bz}}$ & KW PSL & KWW PGPS ${ }^{x}$ & KW PO RP & KW PO RP & KW PiS \\
\hline \multirow[t]{3}{*}{ Kamień } & $\mathbf{Z K}^{\mathrm{b} \tilde{z}}$ & KWW WS ${ }^{\mathbf{b}}$ & KW PO RP & KW PO RP & KW PSL & KWW NGNPar \\
\hline & SLD & KWW „FK”h & KWW FK ${ }^{y}$ & KW PSL & KWW NGNPar & KKW PNKO \\
\hline & $\mathrm{PiS}^{\mathrm{bz̀}}$ & KWW SLD-UP & KWW WS ${ }^{b}$ & KWW IG ${ }^{\text {aj }}$ & KW PO RP & KW PiS \\
\hline \multirow[t]{3}{*}{ Lobez } & - & KWW „PdG”c & KWW PdG & KWW PdG ${ }^{c}$ & KW PSL & KW PSL \\
\hline & & KWW SLD-UP & KWW GPWS & KWW PdM ${ }^{\mathrm{ak}}$ & KWW PPas & KWW PiWax \\
\hline & & KW SRP ${ }^{\mathrm{ck}}$ & KW SRP ${ }^{\mathrm{ck}}$ & KW PSL & KWW PS & KWW PS \\
\hline \multirow[t]{3}{*}{ Myślibórz } & Lista SLD & KWW SLD-UP & KWW SR & KW PO RP & KW PSL & KW PiS \\
\hline & KW AWS & KWW WdP ${ }^{i}$ & KW PO RP & KW SLD & KW PiS & KKW PNKO \\
\hline & UW & KWW PL & KW PiS & KW PiS & KW PO RP & KWW SOS \\
\hline \multirow[t]{3}{*}{ Police } & AWS & KWW „WSG”d & KW PO RP & KW PO RP & KWW GXXI ${ }^{\text {al }}$ & KW WSG ${ }^{a z}$ \\
\hline & Lista SLD & KWW SLD-UP & KW SWSG ${ }^{z}$ & KWW GXXI ${ }^{a l}$ & KW PO RP & KKW PNKO \\
\hline & UW & KW PO RP & KW PiS & KW PiS & KW PiS & KW PiS \\
\hline \multirow[t]{3}{*}{ Pyrzyce } & KW CPR ${ }^{\text {ca }}$ & KWW SLD-UP & KW PO RP & KW PO RP & KW PSL & KW PiS \\
\hline & Lista SLD & KWW CPZP' & KWW WdZP'аa & KW PSL & KW PO RP & KW PSL \\
\hline & $\mathrm{PS}^{\mathrm{bz}}$ & KW SRP ${ }^{\mathrm{ck}}$ & KW PSL & KWW AdPar & KWW SS ${ }^{\text {at }}$ & KKW PNKO \\
\hline \multirow[t]{3}{*}{ Stargard } & Lista SLD & KWW SLD-UP & KW PO RP & KW PO RP & KWW SPS ${ }^{a m}$ & KWW RZ ${ }^{\mathrm{a} \dot{a}}$ \\
\hline & AWS & KWW PS ${ }^{1}$ & KKW LiD & KW SLD & KW PSL & KW PiS \\
\hline & UW & KW SRP ${ }^{\mathrm{ck}}$ & KW PiS & KWW SPS ${ }^{\text {am }}$ & KW PiS & KKW PNKO \\
\hline \multicolumn{7}{|c|}{ Poviats included in constituency no. 40 in the elections to the Sejm of the Republic of Poland } \\
\hline \multirow[t]{3}{*}{ Białogard } & KrKW SLD & KWW PSB ${ }^{\mathrm{e}}$ & KWW PSB ${ }^{\mathrm{e}}$ & KWW PSB ${ }^{\mathrm{e}}$ & KWW PSPB ${ }^{\text {au }}$ & KKW PNKO \\
\hline & KW „PR”cb & KWW SLD-UP & KW PO RP & KW PO RP & KW PO RP & KWW WS ${ }^{\mathrm{az}}$ \\
\hline & ${\mathrm{FS}-Z B^{\mathrm{cc}}}^{\mathrm{c}}$ & KWW WS & KKW LiD & KW SLD & KW PSL & KW PiS \\
\hline \multirow[t]{3}{*}{ Choszczno } & Lista SLD & KWW SLD-UP & KW PSL & KW PO RP & KW PSL & KKW PNKO \\
\hline & $\mathrm{PS} \mathrm{ZCh}^{\text {cd }}$ & KW PSL & KKW LiD & KW PSL & KW PO RP & KW PiS \\
\hline & $\mathrm{PS}^{\mathrm{bz}}$ & KWW PS ${ }^{1}$ & KW PiS & KWW PSiLPC $^{\text {an }}$ & KKW SLD LR & KW PSL \\
\hline \multirow[t]{3}{*}{ Drawsko } & KrKW SLD & KWW SLD-UP & KKW LiD & KW SLD & KW PSL & KW PiS \\
\hline & KW AWS & KWW ŁND ${ }^{\mathrm{m}}$ & KWW PR ${ }^{\mathrm{ab}}$ & KW PO RP & KWW LPS & KWW „PD”ba \\
\hline & $\mathrm{WPD}^{\mathrm{ce}}$ & KWW SiP ${ }^{n}$ & KWW NFS"PD"ac & KWW NGNP ${ }^{\text {ao }}$ & KW PiS & KKW SLD LR \\
\hline \multirow[t]{3}{*}{ Kołobrzeg } & KrKW SLD & KWW SLD-UP & KW PO RP & KW PO RP & KW PO RP & KKW PNKO \\
\hline & KW AWS & KWW „CPR” & KW PiS & KW SLD & KKW SLD LR & KW PiS \\
\hline & SF ZK ${ }^{\mathrm{cf}}$ & KW SRP ${ }^{c k}$ & KKW LiD & KW PiS & KW PiS & KKW SLD LR \\
\hline \multirow[t]{3}{*}{ Koszalin } & KrKW SLD & KWW SLD-UP & KWW PFS ${ }^{\text {ad }}$ & KW PSL & KW PSL & KW PSL \\
\hline & $\mathrm{KW}$, ,CS”cg & KWW PSN ${ }^{p}$ & KW PSL & KW PO RP & KW PO RP & KW S"PS"bb \\
\hline & KW AWS & KW SRPck & KW PO RP & KWW PFS ${ }^{\text {ad }}$ & KWW PFS ${ }^{\text {ad }}$ & KW PiS \\
\hline \multirow[t]{3}{*}{ Sławno } & KrKW SLD & KWW SLD-UP & KW SRP $P^{c k}$ & KW PO RP & KW PSL & KWW PP ${ }^{a s}$ \\
\hline & $\mathrm{PS}^{\mathrm{bz}}$ & KW SRP ${ }^{c k}$ & KWW FSS ${ }^{\text {ae }}$ & KW PSL & KW PO RP & KW PiS \\
\hline & WdP AWS ${ }^{\mathrm{ch}}$ & KWW FS ${ }^{q}$ & KW PiS & KW PiS & KKW SLD LR & KW PSL \\
\hline
\end{tabular}




\begin{tabular}{|c|c|c|c|c|c|c|}
\hline 1 & 2 & 3 & 4 & 5 & 6 & 7 \\
\hline \multirow[t]{3}{*}{ Szczecinek } & KrKW SLD & KWW SLD-UP & KW PO RP & KW PO RP & KW PO RP & KKW PNKO \\
\hline & KW AWS & KWW PS & KWW PS & KWW PS & KWW PS & KW PSPS ${ }^{\mathrm{bc}}$ \\
\hline & Zarząd UW & KWW PPP ${ }^{r}$ & KW PiS & KW SLD & KW PSL & KW PiS \\
\hline \multirow[t]{3}{*}{ Świdwin } & KrKW SLD & KWW SLD-UP & KWW PŚR ${ }^{\text {af }}$ & KWW PŚR ${ }^{\text {af }}$ & KWW PŚR ${ }^{\text {af }}$ & KWW PŚR ${ }^{\text {af }}$ \\
\hline & PFS-G ${ }^{\mathrm{ci}}$ & KW PSL & KWW PWSwŚag & KW PSL & KW PSL & KW PSL \\
\hline & $\mathrm{PS}^{\mathrm{bz}}$ & KW SRP ${ }^{c k}$ & KW PSL & $\begin{array}{ll}\text { KWW } & \text { PWS- } \\
\text { WS' }^{\text {ag }} & \end{array}$ & KWW OS ${ }^{\text {aw }}$ & KW PiS \\
\hline \multirow[t]{3}{*}{ Wałcz } & KrKW SLD & KWW SLD-UP & KWW ORSP ${ }^{t}$ & KW PO RP & KW PO RP & KWW RS ${ }^{\text {bd }}$ \\
\hline & KW AWS & KWW PSPW & KKW LiD & KWW „WP”ap & KW PiS & KW PiS \\
\hline & KW US ${ }^{\mathrm{cj}}$ & KWW ORSP ${ }^{t}$ & KW PO RP & KWW A ${ }^{\text {aq }}$ & KWW WPap & KWW „N",be \\
\hline
\end{tabular}

*w 1998 r. Łobez poviat did not exist; a KWW Samorządowy KW „Razem”; bWW Wspólnota Samorządowa;

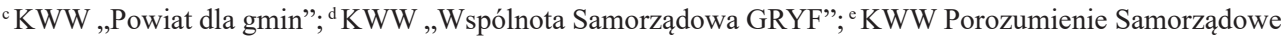
Białogard; ${ }^{\mathrm{f}} \mathrm{KWW}$ Współpraca i Rozwój; ${ }^{\mathrm{g}} \mathrm{KWW}$ Inicjatywa Samorządowa; ${ }^{\mathrm{h}} \mathrm{KWW}$ „Forum Kamieńskie”; ${ }^{\mathrm{i}} \mathrm{KWW}$ Wspólnie dla Powiatu; ${ }^{j} \mathrm{KWW}$ Porozumienie Ludowe; ${ }^{\mathrm{k}} \mathrm{KWW}$ Centro-Prawica Ziemi Pyrzyckiej; ${ }^{1}$ KWW Platforma Samorządowa; ${ }^{1}$ KWW Porozumienie Samorządowe; ${ }^{m}$ KWW Łączy nas Drawa; ${ }^{\text {n }}$ KWW Samorządność i Przedsiębiorczość; KWW „CentroPrawica Razem”; ${ }^{\circ}$ KWW Porozumienie Samorządowe Niezależni; ${ }^{q}$ KWW Forum Samorządowe; ${ }^{\mathrm{r}} \mathrm{KWW}$ Porozumienie Ponad Podziałami; ${ }^{\mathrm{s}} \mathrm{KWW}$ Porozumienie Samorządowe Powiatu Wałeckiego; ${ }^{\mathrm{t}} \mathrm{KWW}$ Obywatelski Ruch Samorządowy Przyszłość; " KWW Idzie-

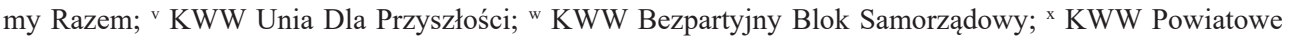
Gryfińskie Porozumienie Samorządowe; ${ }^{\text {y }}$ KWW Forum Kamieńskie; ${ }^{z}$ KWW Gmina, Powiat - Wspólna Sprawa; ${ }^{z}$ KWW Samorząd Razem; ${ }^{\grave{2}}$ KW Stowarzyszenia Wspólnota Samorządowa - Gryf; ${ }^{\text {aa }}$ KWW

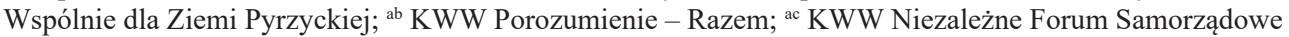
„Pojezierze Drawskie”; ad KWW Powiatowe Forum Samorządowe; ae KWW Forum Samorządowe Sławno; ${ }^{\text {af }}$ KWW Powiat Świdwiński Razem; ag KWW Powiatowa Wspólnota Samorządowa w Świdwinie; ${ }^{\text {ah }}$ KW Powiatowe Stowarzyszenie Idziemy Razem; ai KWW Ziemia Gryficka; ${ }^{\text {aj }}$ KWW Inicjatywa Gospodarcza; ak KWW Powiat dla Mieszkańców; ${ }^{\text {al }} \mathrm{KWW}$ Gryf XXI; ${ }^{\text {at }} \mathrm{KWW}$ Alternatywa dla Pyrzyc; ${ }^{\text {am }} \mathrm{KWW}$ Sławomira Pajora - Stargard XXI; an KWW Porozumienie Społeczne i Lewica Powiatu Choszczeńskiego; ${ }^{\text {ao }}$ KWW Nasza Gmina, Nasz Powiat - To My; ${ }^{\text {ap }}$ KWW „Wspólny Powiat”; ${ }^{\text {aq }}$ KWW Alternatywa; ${ }^{\text {ar }}$ KWW „Nasza Gmina - Nasz Powiat"; as KWW Przyjazny Powiat; at KWW Skuteczny Samorząd; au KWW Porozumienie Samorządowe - Powiat Białogard; ${ }^{\text {av }}$ KWW Lokalne Porozumienie Samorządowe; ${ }^{\text {aw }}$ KWW Odpowiedzialny Samorząd; ax KWW Przyjaźń i Współpraca; ${ }^{\text {ay }}$ KKW S.O.S. dla Powiatu; ${ }^{\text {az }}$ KW Wspólnota Samorządowa

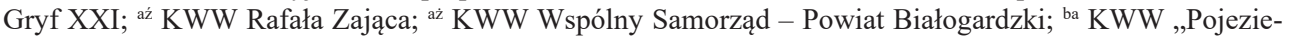

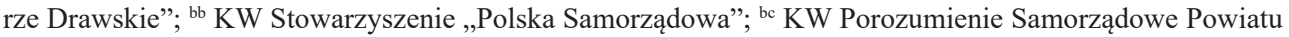
Szczecineckiego; bd KWW Ruch Samorządowy ORS „Przyszłość”; ${ }^{\text {be }}$ KWW „Niezależni”; ${ }^{\text {bw }}$ KW „Inicjatywa Samorządowa" (AWS, SKL, UW i UPR); bx Przymierze Społeczne; by Mieszkańcy dla Mieszkańców

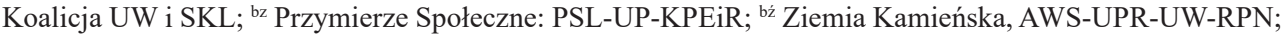
bż Powiatowa Inicjatywa Samorządowa; ${ }^{c a}$ KW Centro-prawica Razem (AWS, SKL, UW); ${ }^{\text {cb }}$ KW „Prawica Razem"; "c Forum Samorządowe - Ziemia Białogardzka; ${ }^{c d}$ Porozumienie Samorządowe Ziemi Choszczeńskiej; ${ }^{c e}$ Wspólnota Powiatowa Drawa; ${ }^{~}{ }^{\circ}$ Samorządowe Forum Ziemia Kołobrzeska; ${ }^{c g} \mathrm{KW}$ „Centrum Samorządowe”; ch Wspólnota dla Powiatu - AWS; ${ }^{\text {ci }}$ Powiatowe Forum Samorządowo-Gospodarcze; ${ }^{\text {cj }} \mathrm{KW}$ Unia Samorządowa; ${ }^{\text {ck }}$ KW Samoobrona RP.

Source: Own study based on PKW data.

\section{Elections of city councils in cities where presidents exercise power}

In Szczecin, the names of committees established or co-created by SLD during elections to the city council did not differ from those for the SWZ. Similar was true for the Platform. In 2002, together with PiS, she co-founded KWW POPiS for Szczecin (Kubaj, 2003, pp. 85-86). However, in each subsequent election, the names of the committees did not differ from those for the SWZ. The same situation also applies to PiS, which, 
apart from the aforementioned year 2002, in all subsequent elections, registered committees under the name of the SWZ (Państwowa Komisja Wyborcza).

As in Szczecin, also in Koszalin, the Alliance created or co-founded committees with the same names as those for the SWZ. In 2002, as a result of the conflict in the SLD in Koszalin (concerning, inter alia, the selection of a candidate for the mayor of the city), the second left-wing committee of the KWW "Local Government Forum G12" was registered, consisting of former Alliance activists (KOV, 2002b; m, 2002a, b, c). As a result, the blurring of support for the two left-wing committees led to the victory of the PO RP. On the other hand, the aforementioned Platform, which in 2002 created KWW POPiS Koszalin with PiS, registered committees with the same name as for the SWZ in subsequent elections. Also PiS, apart from the joint committee with the PO RP in 2002, registered committees with the same name as for the Seymik (Państwowa Komisja Wyborcza) in the remaining elections.

In Świnoujście, as in Szczecin and Koszalin, the names of the committees co-created by SLD did not differ from those of the SWZ. As it turned out, there was a conflict in the left-wing coalition in Świnoujście regarding the choice of a candidate for the mayor of the city. This time SLD activists clashed with the UP. Ultimately, the members of the UP, with the consent of the party's national authorities, ran from the KW list of the "Nowa Fala" Self-Government Society. Moreover, the local UP activists tried to block the establishment of the KW SLD-UP without success (Lachowska, 2002; KOV, 2002a). In contrast, the Civic Platform in 2002, unlike Szczecin and Koszalin, did not co-create a committee with PiS, but under its own name, KW PO RP. On the other hand, in the next elections the names of the committees did not differ from those for the Sejmik. Regarding PiS, in 2002, candidates from this party ran from the KWW Law and Self-government - Świnoujście (KWW PiS-Ś). However, in all subsequent elections, PiS registered committees under the name of the SWZ (Państwowa Komisja Wyborcza).

During the elections in 2002-2014, as in cities with poviat rights, the Alliance co-founded committees in Stargard with names such as the SWZ. In turn, in 2018, instead of the KKW SLD-LR, KWW Wyborcza Lewica - Nasz Stargard (KWW PWL-NS) was registered. In 2002, the Platform did not create its own committee, but was part of the KWW Self-Government Platform (KWW PS), which it co-founded with the UW, the Social Movement and the Conservative People's Party - the New Poland Movement (Pd, 2002). In the years 2006 and 2010, the Platform has been already registering the committees independently under its own name, KW PO RP. In turn, in 2014, it did not create its own committee, while Zofia Ławrynowicz, MP from the PO RP, appointed Sławomir Pajor and Zofia Lawrynowicz (KWW SPiZŁ), together with the mayor of the city, Sławomir Pajor. Also in 2018, the Platform did not create its own committee. However, unlike the previous elections, no committee was registered which would refer to, for example, the abbreviation of the party's name or the name and surname of a well-known politician from this party. In 2002, PiS was part of the KWW Prawica Samorządowa (KWW PrS). However, in all subsequent elections, it registered committees under the same name as for the Sejmik (Drążek, 2002; Państwowa Komisja Wyborcza).

During the 2002-2010 elections, the names of the committees established by the Alliance in Kołobrzeg did not differ from those of the SWZ. However, in 2014, the Alli- 
ance not only did not establish its own committee, but also did not co-create a committee whose name could be guessed to be a left-wing committee. A similar situation took place in 2018, with the difference that the committee of the former SLD activist Zbigniew Błaszczak, Zbigniew Błaszczak, "You have choice," was registered. In 2002, the Platform, together with PiS, UW and the former AWS, were part of KWW "CentroPrawica Razem" (KWW “CPR") (bar, 2002).However, in the years 2006-2014, the PO RP was registering committees under the name of the SWZ. In turn, in 2018 it did not create its own committee. However, the KWW of Anna Mieczkowska "Kołobrzescy Razem" (KWW AM "KR") was registered. It should be noted that A. Mieczkowska, although she belonged to the Civic Platform since 2003, ran from her own committee both to the city council and to the office of the president of Kołobrzeg. In turn, in 2002, PiS, as already mentioned, co-founded the KKW "CPR." In 2006 and 2010, it registered committees with the same names as those for the Sejmik. However, in 2014, it did not register its own, nor did it co-create a committee which would include, for example, the abbreviation of the party's name. In 2018, however, the committee re-registered the name of the Sejmik (Państwowa Komisja Wyborcza).

Analyzing the results of the elections in the scale of all five cities, it can be seen that in the elections held in 1998 and 2002, the SLD and SLD-UP committees definitely enjoyed the greatest support. In 1998, the Alliance won in all 5 cities, while in the next elections, the SLD-UP coalition won in 4 cities and took second place in 1. Since 2006, there is a visible change in electoral preferences, because in the elections of 2006 and 2010, the LiD and SLD committees were giving way to the PO, but outpacing PiS, while in the 2014 and 2018 elections they were behind both the PO RP and PiS. The exception is Świnoujście, where since 1998 (and also in 1994) the committees established or co-created by SLD (Państwowa Komisja Wyborcza) have won. See tables 6 and 7.

Compared to SLD and PiS, since 2006, the platform has achieved the best results in the scale of the five analyzed cities. However, it can be noticed that it enjoyed the greatest support during the elections in 2006 and 2010, when it won in 4 cities, and in one (the aforementioned Świnoujście) it was second.In contrast, in the 2014 election, PO RP won in 3 cities, and in 2, she took second place, while in the last elections of 2018, she also won in 3 cities (although in Kołobrzeg not as KKW PN-KO, but as the aforementioned committee of Anna Mieczkowska), and in 1 it was placed third. Moreover, it did not form its own committee in Stargard, nor in a coalition with Nowoczesna (Państwowa Komisja Wyborcza). See tables 6 and 7.

In turn, when analyzing the results of PiS in cities where presidents exercise power, it can be seen that the party is only just building its position in them. So far, it has not achieved any victory for them. In the 2006 elections, it came second in 2 cities and third in 3 cities. In the next elections in 2010, it took second place only in 1 city, similarly to the third place. However, in 3 cities it was outside the top three. In 2014, it won again in 2 cities, in 1 it was placed third, and in 1 it was beyond the top three. Moreover, PiS did not register the committee in Kołobrzeg. During the last election in 2018 , this grouping achieved the best result so far, as it won second place in 3 cities, third in 1, and outside the top three (Państwowa Komisja Wyborcza) in 1. See tables 6 and 7. 
Results of the elections of selected committees to city councils governed by the presidents of Western Pomerania in 1998-2018

\begin{tabular}{|c|c|c|c|c|c|c|c|c|c|c|c|c|c|c|c|c|c|c|c|c|c|c|c|c|}
\hline \multirow{3}{*}{$\begin{array}{l}\text { Name } \\
\text { of the } \\
\text { party }\end{array}$} & \multicolumn{24}{|c|}{ Victories in presidential counties and cities } \\
\hline & \multicolumn{4}{|c|}{1998} & \multicolumn{4}{|c|}{2002} & \multicolumn{4}{|c|}{2006} & \multicolumn{4}{|c|}{2010} & \multicolumn{4}{|c|}{2014} & \multicolumn{4}{|c|}{2018} \\
\hline & $\mathbf{I}^{\mathbf{1}}$ & $\mathrm{II}^{2}$ & III $^{3}$ & $\mathbf{I}^{4}$ & $\mathbf{I}$ & II & III & i & I & II & III & i & I & II & II & i & $\mathbf{I}$ & II & III & $\mathbf{i}$ & I & II & III & i \\
\hline \multicolumn{25}{|c|}{ Cities ruled by presidents } \\
\hline PO RP & \multirow{2}{*}{\multicolumn{4}{|c|}{-}} & & 0 & \multirow{2}{*}{$1^{\mathrm{b}}$} & 1 & 4 & 1 & 0 & 0 & 4 & 1 & 0 & 0 & 3 & 2 & 0 & 0 & 3 & 0 & 1 & 0 \\
\hline PiS & & & & & & 0 & & 0 & 0 & 2 & 3 & 0 & 0 & 1 & 1 & 3 & 0 & 2 & 1 & 1 & 0 & 3 & 1 & 1 \\
\hline SLD & 5 & 0 & 0 & 0 & 4 & 1 & 0 & 0 & 1 & 2 & 2 & 0 & 1 & 2 & 1 & 1 & 1 & 0 & 0 & 3 & 1 & 0 & 0 & 3 \\
\hline Others & 0 & 5 & 5 & - & 0 & 4 & 4 & - & 0 & 0 & 0 & - & 0 & 1 & 3 & - & 1 & 1 & 4 & - & 2 & 2 & 3 & - \\
\hline
\end{tabular}

${ }^{1}$ First place; ${ }^{2}$ Second place; ${ }^{3}$ Third place; ${ }^{4}$ Place outside the top three; ${ }^{a}$ KWW POPiS Koszalin; ${ }^{b}$ KWW POPiS for Szczecin.

Source: Own study based on PKW data.

Table 7

The results of the elections (the first three committees) for city councils governed by the presidents of Western Pomerania in 1998-2018

\begin{tabular}{|c|c|c|c|c|c|c|}
\hline \multirow{2}{*}{ Poviat } & \multicolumn{6}{|c|}{ The names of the first three committees } \\
\hline & 1998 & 2002 & 2006 & 2010 & 2014 & 2018 \\
\hline \multirow{3}{*}{ Szczecin } & SLD & KKW SLD-UP & KW PO RP & KW PO RP & KW PO RP & KKW PNKO \\
\hline & AWS & KWW TL ${ }^{\mathrm{d}}$ & KW PiS & KW PiS & KW PiS & KWW PKB \\
\hline & UW & KWW POPiS & KKW LiD & KW SLD & B KWW PK ${ }^{1}$ & KW PiS \\
\hline \multirow{3}{*}{ Koszalin } & KrKW SLD & KWW POPiS & KW PO RP & KW PO RP & KW PO RP & KKW PNKO \\
\hline & KW AWS & KKW SLD-UP & KKW LiD & KW SLD & KW LK ${ }^{\mathrm{h}}$ & KW PiS \\
\hline & $\mathrm{ZUW}^{\mathrm{a}}$ & KWW „FS G12” & KW PiS & KW LK ${ }^{\mathrm{h}}$ & KW PiS & KW LK ${ }^{\mathrm{h}}$ \\
\hline \multirow{3}{*}{$\begin{array}{l}\text { Swino- } \\
\text { ujście }\end{array}$} & SLD & KKW SLD-UP & KKW LiD & KW SLD & KKW SLD LR & KKW SLD LR \\
\hline & AWS & KW TS"NF" & KW PO RP & KW PO RP & KW PO RP & KWW JZ̈ \\
\hline & KW „NF”b & KW LPR & KW PiS & KW SGM ${ }^{\mathrm{i}}$ & KW GM-CN & KKW PNKO \\
\hline \multirow{3}{*}{ Stargard } & SLD & KKW SLD-UP & KW PO RP & KW PO RP & KWW SPiZł & KWW RZ \\
\hline & AWS & KWW PS ${ }^{g}$ & KKW LiD & KWW SPS & KW PiS & KW PiS \\
\hline & UW & KW Samoobrona RP & KW PiS & KW PiS & B KWW MP ${ }^{m}$ & KWW PWL-NS \\
\hline \multirow{3}{*}{ Kołobrzeg } & KrKW SLD & KKW SLD-UP & KW PO RP & KW PO RP & KWW WD ${ }^{\mathbf{n}}$ & KWW AM KR \\
\hline & SPMZK $^{c}$ & KWW „CPR” & KW PiS & KW SLD & KW PO RP & KW PiS \\
\hline & KW AWS & KW Samoobrona RP & KKW LiD & KWW HBं & KWW JW ${ }^{\circ}$ & KWW JW ${ }^{\circ}$ \\
\hline
\end{tabular}

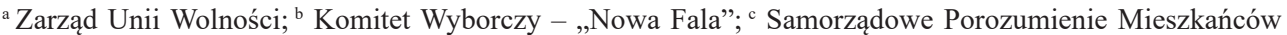
Ziemi Kołobrzeskiej; ${ }^{d} \mathrm{KWW}$ Teresa Lubińska; ${ }^{\mathrm{e}} \mathrm{KWW}$ „Forum samorządowe G-12”; $\mathrm{KW}$ Towarzystwa Samorządowego „Nowa Fala”; ${ }^{g}$ KWW PS; ${ }^{\text {h }}$ KW Lepszy Koszalin; ${ }^{i} \mathrm{KW}$ Stowarzyszenia Grupa Morska;

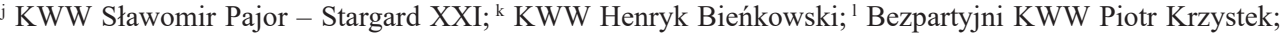
${ }^{1}$ KW Grupa Morska - Cała Naprzód; ${ }^{\mathrm{m}}$ Bezpartyjni KWW Marcin Przepióra - LPS; ${ }^{\mathrm{n}}$ KWW W. Dymecka „Porozumienie dla Kołobrzegu”; ${ }^{\circ}$ KWW Jacek Woźniak; ${ }^{p}$ KWW Piotr Krzystek Bezpartyjni; ${ }^{\mathrm{r}}$ KWW Janusz

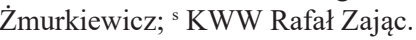

Source: Own study based on PKW data.

By analyzing the results of elections in individual cities in which presidents exercise power in relation to the number of seats won and the support obtained, it is even better to see which of the surveyed groups strengthened or weakened its position. The SLD, which has been operating in various coalition configurations over the years under analysis, is definitely in the worst situation. Apart from the 2002 elections, in which the SLD-UP 
coalition won in four analyzed cities (in Koszalin, the combined forces of PO-PiS already won), it was only worse in each subsequent election. In Szczecin, Koszalin and Stargard, a downward trend can be seen in terms of support gained in individual elections, which translated into a systematic decline in representatives of the Alliance (and its possible coalition partners from the committee) in subsequent terms of city councils. In Kołobrzeg, although the SLD managed to increase its support for the 2006 election in 2010, and thus increase its representation in the city council, the Alliance did not register its committee at all in the next elections in 2014 and 2018. Even in Świnoujście, where the SLD still enjoys the greatest support and wields the power in the city, since the 2014 elections, a decline in support, and thus the number of councilors, can be observed, even though the Alliance remains the strongest party in the city (Państwowa Komisja Wyborcza). See table 8.

The most difficult thing is to draw conclusions from the analysis of support for the PO RP. Although this party remains the strongest party in the analyzed cities and in the vast majority of cases obtains the highest results in elections to city councils (with the exception of the aforementioned Świnoujście), support for this party remains variable. The Platform shows the greatest stability in terms of results in Koszalin. In this city, it always receives the highest support in relation to the other analyzed cities.Moreover, during the last election in 2018, it was the only party to gain over $50 \%$ of the votes. Which of course allowed its - as in 2010 - to exercise power independently. Compared to other groups, the position of the PO RP in Koszalin does not seem to be endangered in any way. The situation is similar in Kołobrzeg, where the Civic Platform remains the strongest party and whose position - despite weaker results in 2014 - remains unchallenged. In Szczecin, in spite of the fact that the Platform in 2006 and 2010 achieved very good results, already in 2014 a clear decrease in support was visible, while in 2018, despite the fact that the PO RP increased its support, and thus the number of its representatives in the city council, however, it did not receive as many seats as in 2006-2010. However, this does not change the fact that each time the PO RP obtained the greatest support in relation to other committees. In Stargard, the Platform, despite gaining the highest support compared to other committees, was systematically losing support from election to election. In the moment of "appear" after the S.Payor's death, one of his closest co-workers - Rafał Zając, this latter dominated the city's political scene. However, in Świnoujście, although the PO remains the second political force, since the 2014 elections, the distance between it and PiS has clearly decreased (Państwowa Komisja Wyborcza). See table 8.

Analyzing the results of PiS in cities where presidents exercise power, it can be seen that this grouping, despite changes in individual elections as to the level of support, in terms of seats won, shows the most stable position in Świnoujście. Moreover, in the last two elections, it narrowed the distance between this party and the Platform in the aforementioned city. In Szczecin, besides the 2010 election, PiS has been consistently increasing its support. In the last elections in 2018, it obtained the highest result so far. In Koszalin, dominated by the Civic Platform, PiS has clearly increased its support since the last two elections, also obtaining the best result in 2018 in this city so far. It is also worth noting that although PiS is separated from the PO by a gap in the scale of support, PiS has definitely outstripped and distanced the SLD since the 2014 election. On the other hand, in Stargard, although support for PiS has increased slightly since the 2014 elections, the party has not even come close to the support it enjoyed in this city in 2006. On the other 
hand, in Kołobrzeg, in the elections in 2006-2014, PiS clearly gave way to the PO RP and, to a lesser extent, SLD, losing support from elections to elections, it significantly strengthened its position after the 2018 elections, obtaining the best result so far. This allowed PiS to place itself in the position of the second political force in the city. However, despite the aforementioned strengthening, this grouping has not yet threatened the leadership position occupied by the Platform (Państwowa Komisja Wyborcza). See table 8.

Table 8

Results of the SLD, PO and PiS elections to city councils governed by presidents in the years 2002-2018 in Western Pomerania

\begin{tabular}{|c|c|c|c|c|c|c|c|c|c|c|c|c|c|c|}
\hline \multirow{2}{*}{$\mathbf{K}^{1}$} & \multicolumn{2}{|c|}{2002} & \multicolumn{3}{|c|}{2006} & \multicolumn{3}{|c|}{2010} & \multicolumn{3}{|c|}{2014} & \multicolumn{3}{|c|}{2018} \\
\hline & $\mathbf{M}^{2}$ & $\% \mathrm{gl}^{3}$ & M & $\% \mathrm{gl}$ & $\mathbf{P} / \mathbf{S}^{4}$ & M & $\%$ gl & $\mathbf{P} / \mathbf{S}$ & M & $\%$ gl & $\mathbf{P} / \mathbf{S}$ & M & $\% \mathrm{gl}$ & $\mathbf{P} / \mathbf{S}$ \\
\hline \multicolumn{15}{|c|}{ Szczecin } \\
\hline SLD & 14 & 25.52 & 6 & 20.14 & -5.38 & 6 & \begin{tabular}{|l|}
17.67 \\
\end{tabular} & -2.47 & 2 & 10.72 & -6.95 & 0 & 7.32 & -3.40 \\
\hline $\mathrm{PO}$ & \multirow{2}{*}{5} & \multirow{2}{*}{11.10} & 15 & 41.19 & \begin{tabular}{|l|}
30.09 \\
\end{tabular} & 15 & 33.40 & -7.79 & 10 & 27.11 & -6.29 & 13 & 34.33 & +7.22 \\
\hline PiS & & & 10 & 23.72 & +12.62 & 7 & 20.62 & -3.10 & 10 & 22.17 & +1.55 & 10 & 26.06 & +3.89 \\
\hline Others & 12 & 35.55 & 0 & - & - & 3 & 16.68 & - & 9 & 27.62 & - & 8 & 26.53 & - \\
\hline \multicolumn{15}{|c|}{ Koszalin } \\
\hline SLD & 9 & 28.24 & 6 & 22.52 & -5.72 & 5 & 17.73 & -4.79 & 2 & 12.53 & -5.20 & 0 & 7.17 & -5.36 \\
\hline $\mathrm{PO}$ & \multirow{2}{*}{10} & \multirow{2}{*}{32.55} & 10 & 29.92 & -2.63 & 14 & 42.99 & +13.07 & 12 & 40.91 & -2.08 & 19 & 50.51 & +9.60 \\
\hline PiS & & & 4 & 18.99 & -13.56 & 3 & 15.21 & -3.78 & 5 & 21.23 & +6.02 & 6 & 22.90 & +1.67 \\
\hline Others & 6 & 27.43 & 5 & 21.19 & - & 3 & 16.38 & - & 6 & 21.98 & - & 0 & - & - \\
\hline \multicolumn{15}{|c|}{ Świnoujście } \\
\hline SLD & 9 & 26.37 & 6 & 25.28 & -1.09 & 10 & 36.64 & +11.36 & 9 & 35.77 & -0.87 & 6 & 24.87 & -10.90 \\
\hline $\mathrm{PO}$ & 0 & 4.73 & 3 & 15.86 & +11.13 & 5 & 21.54 & +5.68 & 5 & 20.36 & -1.18 & 4 & 18.69 & -1.67 \\
\hline PiS & $0^{\mathrm{a}}$ & 4.51 & 3 & 13.30 & +8.79 & 3 & 11.76 & -1.54 & 3 & 18.42 & +6.66 & 3 & 16.90 & -1.52 \\
\hline Others & 12 & 48.50 & 9 & 45.56 & - & 3 & 21.19 & - & 4 & 19.64 & - & 8 & 36.11 & - \\
\hline \multicolumn{15}{|c|}{ Stargard } \\
\hline SLD & 11 & 34.84 & 7 & 24.81 & -10.03 & 3 & 15.90 & -8.91 & 3 & 13.46 & -2.44 & $1^{\mathrm{f}}$ & 9.83 & -3.63 \\
\hline $\mathrm{PO}$ & $5^{b}$ & 18.38 & 9 & 33.75 & +15.37 & 9 & 31.49 & -2.26 & $6^{\mathrm{e}}$ & 25.34 & -6.15 & - & & \\
\hline PiS & $1^{\mathrm{c}}$ & 8.39 & 7 & 27.43 & +19.04 & 4 & 18.83 & -8.60 & 3 & 20.44 & +1.61 & 4 & 20.58 & +0.14 \\
\hline Others & 6 & 23.60 & 0 & - & - & 7 & 27.34 & - & 11 & 33.70 & - & 18 & 69.60 & - \\
\hline \multicolumn{15}{|c|}{ Kołobrzeg } \\
\hline SLD & 9 & 33.50 & 3 & 16.08 & -17.42 & 5 & 22.81 & +6.73 & & - & & - & & \\
\hline $\mathrm{PO}$ & \multirow{2}{*}{$8^{\mathrm{d}}$} & \multirow{2}{*}{32.17} & 10 & 33.51 & +1.34 & 11 & 42.19 & +8.68 & 7 & 30.94 & -11.25 & $10^{\mathrm{g}}$ & 38.50 & +7.56 \\
\hline PiS & & & 3 & 15.29 & -16.88 & 1 & 13.16 & -2.13 & & - & & 6 & 26.09 & +12.93 \\
\hline Others & 4 & 23.25 & 5 & 21.81 & - & 4 & 21.84 & - & 14 & 53.52 & - & 5 & 23.23 & - \\
\hline
\end{tabular}

${ }^{1}$ The name of the committee; ${ }^{2}$ Number of seats; ${ }^{3} \%$ of votes; ${ }^{4}$ Increase or decrease in votes in $\% ;{ }^{a} \mathrm{KWW}$ PiS-Ś; ${ }^{b} \mathrm{KWW}$ PS; ' KWW PrS; ${ }^{\mathrm{d}} \mathrm{KWW}$ “CPR”; ${ }^{\mathrm{e}} \mathrm{KWW}$ SPiZL; ${ }^{\mathrm{f}} \mathrm{KWW}$ PWL-NS; ${ }^{\mathrm{g}} \mathrm{KWW}$ AM“KR".

Source: Own study based on PKW data.

Assuming that the support received by the analyzed committees for the SWZ reflects their support on the scale of Western Pomerania, then by referring the results of the elections to city councils in which presidents exercise power, one can see which cities are or were favorable political ground for individual parties, and in which they are not as popular as in the province.

Comparing the results of the SLD, it can be seen that in the vast majority of elections (except for 2002) the Alliance enjoys clear support in Świnoujście, where it received 
a dozen or several dozen times greater support than for the Seymik. No other party enjoyed such support in any other city. The second city in which SLD noted greater support (with the exception of 2010) was Stargard, although the advantage was not as large as in the case of Świnoujście. In Szczecin, the party under discussion, with the exception of the 2006 elections, obtained worse results than to the Sejmik. In Kołobrzeg, although it gained more support in the elections of 2002 and 2010, it did not even register a committee in the elections of 2014 and 2018. However, in Koszalin no tendency was found (Państwowa Komisja Wyborcza). See table 9.

Since the elections of 2010 and in Kołobrzeg, the PO had more support than the SWZ in Koszalin, with the exception of 2014. In Szczecin, apart from the elections of 2006 and 2018, the party's results were weaker than in the Sejmik. In Stargard, on the other hand, it can be seen that, apart from the 2006 election, where the result was slightly better than for the Sejmik, the tendency was reversed in the remaining years. In turn, the city where the Platform obtained the worst results in relation to SWZ was Świnoujście (Państwowa Komisja Wyborcza). See table 9.

In contrast, PiS received more support than the Sejmik in Szczecin, with the exception of 2018, where it obtained a slightly worse result, and in Stargard, also excluding the 2018 elections. In turn, in Koszalin (with the exception of the 2014 elections), Kołobrzeg and in Świnoujście, PiS obtained worse results than in the Sejmik (Państwowa Komisja Wyborcza). See table 9.

Table 9

Results of the SLD, PO and PiS elections to city councils in which the presidents in 2002-2018 in Western Pomerania held their office

\begin{tabular}{|c|c|c|c|c|c|c|c|c|c|c|c|c|c|c|c|}
\hline \multirow{2}{*}{$\mathbf{K}^{1}$} & \multicolumn{3}{|c|}{2002} & \multicolumn{3}{|c|}{2006} & \multicolumn{3}{|c|}{2010} & \multicolumn{3}{|c|}{2014} & \multicolumn{3}{|c|}{2018} \\
\hline & $\overline{\mathbf{S W Z}}$ & $\mathbf{R M}^{3}$ & $\mathbf{P} / \mathbf{S}^{4}$ & SWZ & $\mathbf{R M}$ & $\mathbf{P} / \mathbf{S}$ & SWZ & $\mathbf{R M}$ & $\mathbf{P} / \mathbf{S}$ & SWZ & $\mathbf{R M}$ & $\mathbf{P} / \mathbf{S}$ & SWZ & $\mathbf{R M}$ & $\mathbf{P} / \mathbf{S}$ \\
\hline \multicolumn{16}{|c|}{ Szczecin } \\
\hline SLD & 33.17 & 25.52 & -7.65 & 18.45 & 20.14 & +1.69 & 18.52 & 17.67 & -0.85 & 11.82 & 10.72 & -1.10 & 9.08 & 7,32 & $-1,76$ \\
\hline $\mathrm{PO}$ & \multirow{2}{*}{11.20} & \multirow{2}{*}{11.10} & \multirow{2}{*}{-0.10} & 33.36 & 41.19 & +7.83 & 40.80 & 33.40 & -7.40 & 31.94 & 27.11 & -4.83 & 32.04 & 34,33 & $+2,29$ \\
\hline PiS & & & & 20.82 & 23.72 & +2.90 & 18.67 & 20.62 & +1.95 & 19.29 & 22.17 & +2.88 & 26.80 & 26,06 & $-0,74$ \\
\hline \multicolumn{16}{|c|}{ Koszalin } \\
\hline SLD & 33.17 & 28.24 & -4.93 & 18.45 & 22.52 & +4.07 & 18.52 & 17.73 & -0.79 & 11.82 & 12.53 & +0.71 & 9.08 & 7,17 & $-1,91$ \\
\hline PO & \multirow{2}{*}{11.20} & \multirow{2}{*}{32.55} & \multirow{2}{*}{+21.35} & 33.36 & 29.92 & -3.44 & 40.80 & 42.99 & +2.19 & 31.94 & 40.91 & +8.97 & 32.04 & 50,51 & $+18,47$ \\
\hline PiS & & & & 20.82 & 18.99 & -1.83 & 18.67 & 15.21 & -3.46 & 19.29 & 21.23 & +1.94 & 26.80 & 22,90 & $-3,90$ \\
\hline \multicolumn{16}{|c|}{ Świnoujście } \\
\hline SLD & 33.17 & 26.37 & -6.80 & 18.45 & 25.28 & +6.83 & 18.52 & 36.64 & +18.12 & 11.82 & 35.77 & \begin{tabular}{|l|}
+23.95 \\
\end{tabular} & 9.08 & 24,87 & $+15,79$ \\
\hline PO & - & 4.73 & - & 33.36 & 15.86 & -17.50 & 40.80 & 21.54 & -19.26 & 31.94 & 20.36 & -11.58 & 32.04 & 18,69 & $-13,35$ \\
\hline PiS & - & $4.51^{\mathrm{a}}$ & - & 20.82 & 13.30 & -7.52 & 18.67 & 11.76 & -6.91 & 19.29 & 18.42 & -0.87 & 26.80 & 16,90 & $-9,90$ \\
\hline \multicolumn{16}{|c|}{ Stargard } \\
\hline SLD & 33.17 & 34.84 & +1.67 & 18.45 & 24.81 & +6.36 & 18.52 & 15.90 & -2.62 & 11.82 & 13.46 & +1.64 & 9.08 & $9,83^{\mathrm{f}}$ & $+0,75$ \\
\hline $\mathrm{PO}$ & - & $18.38^{\mathrm{b}}$ & - & 33.36 & 33.75 & +0.39 & 40.80 & 31.49 & -9.31 & 31.94 & $25.34^{\mathrm{e}}$ & -6.60 & \multicolumn{3}{|c|}{-} \\
\hline PiS & - & $8.39^{c}$ & - & 20.82 & 27.43 & +6.61 & 18.67 & 18.83 & +0.16 & 19.29 & 20.44 & +1.15 & 26.80 & 20,58 & $-6,22$ \\
\hline \multicolumn{16}{|c|}{ Kolobrzeg } \\
\hline SLD & 33.17 & 33.50 & +0.33 & 18.45 & 16.08 & -2.37 & 18.52 & 22.81 & +4.29 & \multicolumn{3}{|c|}{-} & \multicolumn{3}{|c|}{-} \\
\hline PO & \multirow{2}{*}{11.20} & \multirow{2}{*}{$32.17^{d}$} & \multirow{2}{*}{+20.97} & 33.36 & 33.51 & +0.15 & 40.80 & 42.19 & +1.39 & 31.94 & 30.94 & -1.00 & 32.04 & $38,50^{\mathrm{g}}$ & $+6,46$ \\
\hline PiS & & & & 20.82 & 15.29 & -5.53 & 18.67 & 13.16 & -5.51 & \multicolumn{3}{|c|}{-} & 26.80 & 26.09 & -0.71 \\
\hline
\end{tabular}

${ }^{1}$ The name of the committee; ${ }^{2} \%$ of votes to SWZ; $3 \%$ of votes to the city council; ${ }^{4}$ Increase or decrease in votes in \%; ${ }^{a} \mathrm{KWW}$ PiS-Ś; ${ }^{\mathrm{b}} \mathrm{KWW}$ PS; ${ }^{\mathrm{c}} \mathrm{KWW}$ PrS; ${ }^{\mathrm{d}} \mathrm{KWW}$ "CPR"; ${ }^{\mathrm{e}} \mathrm{KWW}$ SPiZL; ${ }^{\mathrm{f}} \mathrm{KWW}$ PWL-NS; "KWW AM"KR".

Source: Own study based on PKW data. 


\section{Final remarks}

Analyzing the results of the elections in Western Pomerania to the Seymik, poviat councils and cities governed by presidents from 1998-2002, one can undoubtedly conclude that the SLD's domination since the 2006 election has definitely ended. The Alliance, despite a number of various attempts to form electoral coalitions, in various configurations - so far - has not even come close to its lost position and there is no indication that it could again dominate the analyzed region. On the other hand, an opposite situation can be observed, in which the results of the SLD elections together with the coalition partners are getting weaker and weaker. Even in its stronghold, which Świnoujście was considered to be so far, the Alliance, despite its victories, has weaker and weaker support.

So far, since the aforementioned elections in 2006 , the PO has remained the party enjoying the greatest support in the region. However, observing the results that the PO RP and PiS won in the last two elections, especially the 2018 one, it can be seen that the increasingly better results achieved by Jarosław Kaczyński's party deprived the PO RP of the position of hegemon that it held in 2006-2014. Although PiS has strengthened its position as the second political force in the region, it is unlikely that it could threaten the PO's position in the next elections, especially in the Seymik and in the councils of presidential cities.

In turn, the question to what extent the inhabitants of the region changed their electoral preferences from left-wing towards the center or further, and to what extent the PO moved from the center-right to the position of the center-left, thus preventing regaining some of the lost electorate because of SLD, remains open. Analyzing voting preferences in terms of the extreme left, left, center-left, center, center-right, right and extreme right remains difficult. This is due to the fact that the analyzed groups changed their program slogans depending on the period, which often influenced their affiliation to the typology of political parties mentioned in the introduction. Also forming coalitions with parties not always from the same family of political parties, taking electoral lists of politicians who often come from parties with different programs, or having, for example, a left-wing economic program and proclaiming right-wing ideological issues, further distorts this image.

It seems - observing the aforementioned program changes in individual parties - that in Western Pomerania center-left preferences still dominate over center-right ones. This is evidenced by the results of the PO RP, which, after having marginalized its right wing and became a centrist/center-left party according to the ideological and program criterion (or, according to the criterion of basic doctrinal stereotypes, a liberal/social-liberal group), still enjoys the greatest support, effectively marginalizing SLD and keeping PiS at distans.

\section{Bibliography}

bar (2002), Były prezydent na prezydenta, „Kurier Szczeciński”, 12.09.2002.

Buhler P. (1999), Polska droga do wolności 1939-1995, Wydawnictwo Akademickie DIALOG, Warszawa. 
Chrobak P. (2015), Preferencje wyborcze mieszkańców regionu zachodniopomorskiego $w$ pierwszym dwudziestopięcioleciu III Rzeczypospolitej, in: Pomorze Zachodnie z Polska, ed. K. Kozłowski, Naczelna Dyrekcja Archiwów Państwowych w Warszawie, Wydawnictwo Archiwum Państwowego w Szczecinie „Dokument”, Warszawa-Szczecin.

Chrobak P. (2014), Wybory samorządowe w Szczecinie na tle Pomorza Zachodniego w latach 19902010. Preferencje wyborcze mieszkańców regionu zachodniopomorskiego, Wydział Humanistyczny Uniwersytetu Szczecińskiego, Wydawnictwo Archiwum Państwowego „Dokument” w Szczecinie, Szczecin.

Czerwiński M. (2003), Kampania i wyniki wyborów do Sejmiku Województwa Zachodniopomorskiego w 2002 roku, in: Wybory samorzadowe w 2002 roku w Szczecinie, ed. K. Kowalczyk, Wydawnictwo Naukowe Uniwersytetu Szczecińskiego, Szczecin.

Danel Ł. (2008), Polska lewica wobec Unii Europejskiej i wyzwań przed nia stojących - analiza programowa na szczeblu krajowym, in: Polska lewica u progu XXI wieku, ed. Ł. Tomczak, Wydawnictwo MARINA, Wrocław.

Drążek G. (2002), Walka o miasto i powiat, „Głos Stargardzki”, 31.05.2002.

Drzonek M. (2006), Demokraci.pl - wirtualny koniec etosu?, in: Popisy w polityce. Uwagi o polskiej scenie politycznej, ed. M. Drzonek, J. Mieczkowski, Print Group Daniel Krzanowski, Szczecin.

Drzonek M. (2007), Kilka uwag o ordynacji wyborczej, in: Wybory z gryfem w tle. Szkice o wyborach w 2006 roku na Pomorzu Zachodnim, ed. M. Drzonek, Print Group, Szczecin.

Dudek A. (1997), Pierwsze lata III Rzeczypospolitej 1989-1995, Wydawnictwo GEO, Kraków.

Godlewski T. (2008), Lewica i prawica w świadomości społeczeństwa polskiego, Dom Wydawniczy Elipsa, Warszawa.

Górka M. (2017), PO-PiS-owa demokracja. Rywalizacja między PO i PiS w latach 2005-2015, Wydawnictwo Uczelniane Politechniki Koszalińskiej, Koszalin.

Jabłonowski M., Janowski W., Sołtysiak G. (2015), Kongres Założycielski Socjaldemokracji Rzeczypospolitej Polskiej (1990). Polska mniej znana 1944-1989, Wydział Dziennikarstwa i Nauk Politycznych Uniwersytetu Warszawskiego, Archiwum Akt Nowych w Warszawie, Fundacja Archiwum Dokumentacji Historycznej PRL, Oficyna Wydawnicza ASPRA-JR, Warszawa.

Koalicyjne porozumienie wyborcze, 28.09.2018, http://web.archive.org/web/20181106173332/http:// www.kpeir.org/53-koalicyjne-porozumienie-wyborcze-28-09.html, 12.07.2021.

KOV (2002a), Koalicji nie ma, „Gazeta Wyborcza. Szczecin”, 24.09.2002.

KOV (2002b), Mimo SLD, „Gazeta Wyborcza. Szczecin”, 4.09.2002.

Kowalczyk K. (2015), Pomorze Zachodnie - „, bastion PO”? Wybory do Sejmiku Województwa Zachodniopomorskiego w 2014 roku, „Opuscula Sociologica”, nr 3, Szczecin.

Kowalczyk K., Tomczak Ł. (2008), Wybory samorządowe w Szczecinie w 2006 roku, ZAPOL, Szczecin.

Krzeszewska M. (2016), Wizerunek wybranych partii politycznych w Internecie. Wybory do Sejmiku Województwa Zachodniopomorskiego w 2014 roku, in: Wybory samorzadowe na Pomorzu Zachodnim w 2014 roku. Programy - Kandydaci - Kampanie, eds. M. Kamola-Cieślik, Ł. Tomczak, Wydawnictwo Naukowe Wydziału Humanistycznego US MINERWA, Szczecin.

Kubaj A. (2003), Kampania Komitetu Wyborczego Wyborców POPiS dla Szczecina do Rady Miasta Szczecina w 2002 roku, in: Wybory samorzadowe w 2002 roku w Szczecinie, ed. K. Kowalczyk, Wydawnictwo Naukowe Uniwersytetu Szczecińskiego, Szczecin.

Lachowska H. (2002), Razem ale osobno, „Głos szczeciński”, 24.09.2002.

m (2002a), Autorytety wspomoga Zarodę, „Kurier Szczeciński”, 26.09.2002.

m (2002b), Prezydent razem z G-12, „Kurier Szczeciński”, 16.09.2002.

m (2002c), Sobolewski niechciany, ale kandydat, „Kurier Szczeciński”, 6.09.2002. 
Marszałek-Kawa J. (2007), Wybory samorzadowe 2006 a kwestia nowelizacji samorzadowej ordynacji wyborczej, in: Samorząd terytorialny. Studium politologiczne, ed. J. Marszałek-Kawa, Wydawnictwo Adam Marszałek, Toruń.

Państwowa Komisja Wyborcza, https://www.pkw.gov.pl, 12.07.2021.

Paradowska J. (2006), Porozumienie lewicy i demokratów. Wszyscy po przejściach, „Polityka”, nr 36.

Pd (2002), Prawica jednoczy się, „Kurier Szczeciński”, 9.09.2002.

Peszyński W. (2008), Pozycjonowanie oferty politycznej LiD względem PiS w kampaniach 2006 i 2007 roku, in: Demokracja w Polsce po 2005 roku, ed. D. Karnowska, Wydawnictwo Adam Marszałek, Torun.

Piasecki A. K. (2012), Wybory w Polsce 1989-2011, Wydawnictwo ARCANA, Kraków.

Ptak A. (2010), Ewolucja systemu wyborczego do organów samorządu terytorialnego w Polsce, in: Prawo wyborcze i wybory. Doświadczenia dwudziestu lat procesów demokratyzacyjnych w Polsce, ed. A. Stelmach, Wydawnictwo Naukowe Wydziału Nauk Politycznych i Dziennikarstwa UAM, Poznań.

Roszkowski W. (2007), Najnowsza historia Polski 1980-2006, Świat Książki, Warszawa.

Sieklucki D. (2006), Partie lewicy i centrolewicy w polskim systemie partyjnym, Wydawnictwo Uniwersytetu Jagiellońskiego, Kraków.

Sielski J. (2008), Przyczyny i cechy wyróżniajace polski system partyjny, in: Demokracja w Polsce po 2005 roku, ed. D. Karnowska, Wydawnictwo Adam Marszałek, Toruń.

Sielski J. (2006), Przypadek braci Kaczyńskich, in: Popisy w polityce. Uwagi o polskiej scenie politycz$n e j$, eds. M. Drzonek, J. Mieczkowski, Print Group Daniel Krzanowski, Szczecin.

SLD - Lewica Razem - koalicja wyborcza na wybory samorzadowe i do parlamentu europejskiego zawiqzana!, 18.06.2018, https://lewica.org.pl/aktualnosci/3200-sld-lewica-razem-koalicjawyborcza-na-wybory-samorzadowe-i-do-parlamentu-europejskiego-zawiazana-2, 12.07.2021.

Tomczak Ł. (2008a), Efekt grupowania (blokowania) list na przykladzie wyborów do sejmików; udana czy nieudana manipulacja?, in: Demokracja w Polsce po 2005 roku, ed. D. Karnowska, Wydawnictwo Adam Marszałek, Torun.

Tomczak Ł. (2007), Lewicowi demokraci czy demokratyczni lewicowcy - przypadek LiD, in: Opisy politologów. Uwagi o polskiej scenie politycznej, eds. M. Drzonek, J. Mieczkowski, ZAPOL, Szczecin.

Tomczak Ł. (2008b), Polska lewica - konsekwencje podziałów i konsolidacji, in: Polska lewica u progu XXI wieku, ed. Ł. Tomczak, Wydawnictwo MARINA, Wrocław.

Tomczak Ł. (2004), Sojusz Lewicy Demokratycznej, in: Lokalne i krajowe struktury polskich partii politycznych, ed. Ł. Tomczak, Oficyna Wydawnicza CDiDN w Szczecinie, Szczecin.

Ustawa z dnia 16 lipca 1998 roku - ordynacja wyborcza do rad gmin, rad powiatów i sejmików województw, Dz.U. 1998, Nr 95, poz. 602 ze zm., Art. 64 1a.

Wspótczesne partie i systemy partyjne. Zagadnienia teorii i praktyki politycznej (2003), eds. W. Sokół, M. Żmigrodzki, Wydawnictwo Marii Curie-Skłodowskiej, Lublin.

\section{Preferencje wyborcze mieszkańców Pomorza Zachodniego w wyborach samorządowych w III Rzeczypospolitej}

\section{Streszczenie}

Długo o Pomorzu Zachodnim mówiło się, że był to tzw. bastion lewicy, gdyż Sojusz Lewicy Demokratycznej w latach 90-tych XX w., jak i na początku XXI w. osiągał tu jedne z najlepszych wyników w skali kraju. Dopiero po wyborach parlamentarnych i na Prezydenta RP z 2005 r. oraz samorządowych 
z 2006 r. nastąpiła zmiana preferencji wyborczych w kierunku centrum sceny politycznej. Głównym beneficjentem zmiany okazała się Platforma Obywatelska Rzeczypospolitej Polskiej, a mniejszym Prawo i Sprawiedliwość. W artykule analizie politologicznej poddano preferencje wyborcze mieszkańców Pomorza Zachodniego w wyborach samorządowych w odniesieniu do trzech wspomnianych partii. Celem badań było przeanalizowanie, w którą stronę następuje przepływ elektoratu. Sprawdzono czy trwale wyeliminowano SLD i jak silna jest dominacja Platformy. Ponadto przebadano czy PiS realnie zagraża PO RP oraz czy SLD ma szanse odzyskać utraconą pozycję. Wydaje się, że bez względu na podejmowane próby, pozycja SLD po wyborach z 2006 r. jest ustabilizowana i nic nie wskazuje, aby Sojusz mógł ponownie zdominować analizowany region. Natomiast mimo iż od 2006 r. Platforma cieszy się wysokim poparciem, to od 2014 r. coraz lepsze wyniki uzyskuje PiS, pozbawiając PO RP pozycji hegemona jaką zajmowała w latach 2006-2014.

Słowa kluczowe: Pomorze Zachodnie, wybory samorządowe, preferencje wyborcze, partie polityczne 